\title{
Oropharyngeal (p16-Negative) Cancer pM1 TNM Finding v8
}

National Cancer Institute

\section{Source}

National Cancer Institute. Oropharyngeal (p16-Negative) Cancer pM1 TNM Finding v8. NCl Thesaurus. Code C132987.

Oropharyngeal (p16-negative) cancer with distant metastasis. (from AJCC 8th Ed.) 